\title{
ANALISIS KECEPATAN FILTRASI DENGAN JENIS PAKAN YANG BERBEDA TERHADAP KELANGSUNGAN HIDUP SPAT KERANG MUTIARA (Pinctada maxima)
}

\author{
ANALYSIS OF FILTRATION RATE WITH DIFFERENT TYPES OF FEED ON THE \\ SURVIVAL OF OYSTER PEARL (Pinctada maxima) \\ M. Maizi Diploma Putra ${ }^{1}$, Nunik Cokrowati ${ }^{1 *}$, M. Masyarul Rusdani ${ }^{1}$ \\ Program Studi Budidaya Perairan, Universitas Mataram \\ Jl. Pendidikan No. 37 Mataram, NTB.
}

\begin{abstract}
Abstrak
Penelitian ini bertujuan untuk mengetahui kecepatan filtrasi kerang mutiara dengan jenis pakan yang berbeda, untuk selanjutnya ditentukan jenis pakan yang disukai oleh spat kerang mutiara (Pinctada maxima). Penelitian ini dilaksanakan di PT. Autore Pearl Culture, Kecamatan Pemenang, Kabupaten Lombok Utara, NTB pada tanggal 25 April hingga 25 Mei 2017. Penelitian ini menggunakan faktor uji jenis pakan yang berbeda, masing-masing faktor uji terdiri dari 3 perlakuan yaitu pemberian pakan alami dengan jenisIsochrysis galbana, Pavlova lutheri, Chaetoceros sp., dengan kepadatan $270.000 \mathrm{sel} / \mathrm{ml}$. Setiap unit percobaan selanjutnya disusun dalam Rancangan Acak Lengkap (RAL), dengan media pemeliharaan berupa toples plastik volume $5000 \mathrm{ml}$. Pemeliharaan dilakukan selama 30 hari. Parameter yang diamati adalah clearance rate, filtration rate, aktivitas makan, tingkat konsumsi pakan dan tingkat kelangsungan hidup. Data dianalisis menggunakan analisis sidik ragam (ANOVA) dengan taraf nyata 5\%. Hasil penelitian menunjukkan bahwa kecepatan filtrasi dengan pemberian jenis pakan yang berbeda selama pemeliharaan spat kerang mutiara $(P$. maxima) memberikan pengaruh nyata $(p<0,05)$ terhadap kelangsungan hidup spat. Dengan nilai kelangsungan hidup rata-rata tertinggi diperoleh dari pemberian pakan Chaetoceros sp. yaitu sebesar $76.67 \% \pm 19.66$ dibandingkan dengan pemberian Isochrysis galbana, Pavlova lutheri.
\end{abstract}

Kata kunci :P. maxima, kecepatan filtrasi, pakan alami, spat, kelangsungan hidup

\begin{abstract}
The purpose of study was to determine the filtration rate of oyster pearl with different types of feed, in order to determine the type of feed preferences of pearl oyster spat. The research was conducted at PT. Autore Pearl Culture, Pemenang, District, North Lombok Regency, NTB on April 25 to May 25 2017. The experiment used three different type of feed i.e. Isochrysis galbana, Pavlova Lutheri, Chaetoceros sp., with density of 270,000 cells / ml. Experimental was arranged in Completely Randomized Design. Jars volume $5000 \mathrm{ml}$ were used as experimental unit. Spat reared for 30 days. Measured parameter were clearance rate, filtration rate, feeding activity, feed consumption level and survival rate. Data were analyzed using analysis of variance (ANOVA). The results showed that filtration rate with different type of feed affected $(\mathrm{p}<0,05)$ survival rate of spat. Chaetoceros sp resulted the highest average of survival rate of $76.67 \% \pm 19.66$, compare to Isochrysis galbana and Pavlova lutheri.
\end{abstract}

Keywords: P. maxima, speed of filtration, natural feed, spat, survival.

\section{Pendahuluan}

Diantara jenis kerang penghasil mutiara yang ada di Indonesia adalah Pinctada maxima dan sudah tersedia teknologi budidayanya.Semakin bertambah banyaknya jumlah usaha budidaya kerang mutiara, maka kebutuhan akan spat atau benih untuk memenuhi kebutuhan operasi juga terus meningkat. Berdasarkan pernyataan Winanto (2004), tentang permintaan pasar yang cukup tinggi untuk spat kerang mutiara ukuran dibawah $5 \mathrm{~cm}$, seharga Rp 3.000 sampai $\mathrm{Rp}$ 5.000 per $\mathrm{cm}$ menjadikan komoditas tersebut sebagai komoditas budidaya andalan.

Spat biasanya diambil langsung dari alam, namun karena jumlahnya terbatas dan tidak dapat dipastikan menyebabkan kelangsungan 
produksi komoditas sesuai kebutuhan pasar tidak dapat terjamin (Kordi, 2011). Alternatif utama yang dapat ditempuh adalah melakukan penyediaan benih secara buatan melalui hatchery.Tetapi usaha ini masih terus menghadapi beberapa kendala yang diantaranya adalah masih tingginya mortalitas dari larva sampai spat. Antoro dan Erawati (2001) menyatakan bahwa pemeliharaan larva sampai spat umur 30 hari mengalami mortalitas mencapai 97,23\%. Hamzah (2008) dan Adiguna (2004) melaporkan bahwa pemberian pakan campuran I. galbana, $P$. lutheri, dan Chaetoceros sp. memberikan tingkat kelangsungan hidup yang rendah yaitu $10-15 \%$ dan $7,72 \%$. Sedangkan Winanto (2004) menyatakan bahwa masa transisi yang cukup kritis dalam kehidupan spat terjadi setelah spat dipindahkan di laut dan tidak ditangani dengan baik menyebabkan kematian (mortalitas) mencapai 98\%. Hal ini juga dijelaskan oleh Taufiq dkk.(2010) bahwa spat sangat sensitif dan mudah stress sehingga tingkat kematian pada fase ini dapat mencapai 98\%. Faktor penyebab rendahnya kelangsungan hidup adalah pemberian pakan alami yang tidak sesuai bagi larva sampai spat. Hal ini secara umum berkaitan dengan jenis, ukuran, serta nutrisi pakan yang tidak memadai untuk pertumbuhan. Sebab lain adalah faktor lingkungan seperti salinitas, $\mathrm{pH}$, suhu, dan oksigen terlarut (Dhoe dkk., 2001; Taufiq dkk., 2007).

Cara yang dapat dilakukan untuk mengurangi tingginya mortalitas spat kerang mutiara adalah dengan cara meningkatkan dan memperhatikan tingkat penyerapan pakan alami (filtrasi) yang dikonsumsi oleh spat kerang mutiara melalui pemberian pakan alami yang berkualitas dan sesuai dengan bukaan mulut spat, cukup dantepat waktu, serta sesuai dengan kesukaan spat. Sehingga dengan demikian diharapkan dapat meningkatkan kelangsungan hidup dan meningkatkan daya tahan spat, ketersediaan spat untuk pembesaran terpenuhi serta ketersediaan spat terjamin. Tujuan penelitian ini adalah untuk mengetahui kecepatan filtrasi kerang mutiara dengan jenis pakan yang berbeda, untuk selanjutnya ditentukan jenis pakan yang disukai oleh $P$. maxima.

\section{Metode Penelitian}

Penelitian ini dilaksanakan pada tanggal 25 April hingga 25 Mei 2017 di PT. Autore Pearl Culture, Kecamatan Pemenang, Kabupaten Lombok Utara.Biota uji yang digunakan adalah spat $P$. maximadengan ukuran panjang cangkang $1-2 \mathrm{~cm}$ dengan umur kurang dari 2 bulan dari pembenihan di PT. Autore Pearl Culture.

Penelitian ini menggunakan faktor uji jenis pakan yang berbeda, masing-masing faktor uji terdiri dari 3 perlakuan dan 6 ulangan. Perlakuan yang diujikan adalah pemberian pakan alami dengan jenisIsochrysis galbana, Pavlova lutheri,Chaetoceros sp.Setiap unit percobaan selanjutnya disusun dalam Rancangan Acak Lengkap (RAL), dengan media pemeliharaan berupa toples plastik volume $5000 \mathrm{ml}$.

Pengamatan yang dilakukan selama kecepatan filtrasi adalah kecepatan pembersihan partikel (Clearance rate), tingkat kelangsungan hidup, aktivitas makan, dan tingkat konsumsi pakan harian.Data konsentrasi pakan awal dan akhir yang didapatkan tiap jam dapat digunakan untuk menghitungpembersihan partikel dengan menggunakan persamaan dari Libini dkk. (2017) dengan rumus : $\mathrm{CR}=$ $\left(\ln \mathrm{C}_{0}-\ln \mathrm{Ct}\right) /\left(\mathrm{t}-\mathrm{t}_{0}\right) x \mathrm{~V}, \quad$ dimana, $\quad \mathrm{CR}=$ Clearance rate $(1 / \mathrm{jam}) ; \mathrm{V}=$ Volume toples uji (liter); Co = Konsentrasi pakan awal (sel/ml); $\mathrm{Ct}=$ Konsentrasi pakanakhir $(\mathrm{sel} / \mathrm{ml}) ; \mathrm{t}-\mathrm{t}_{0}=$ Jarak waktu (jam).

Data konsentrasi pakan awal dan akhir yang didapatkan tiap jam dapat digunakan untuk menghitung kecepatan filtrasi dengan menggunakan persamaan sebagai dariPetersen dkk. (2004)dengan rumus :FR $=(v / n t) \ln$ $\left(C_{d} / C t\right)$, dimana FR $=$ Kecepatan filtrasi (l/jam); V= Volume toples uji (liter); $\mathrm{n}=$ Jumlah kerang; $\mathrm{Co}=$ Konsentrasi pakanawal $(\mathrm{sel} / \mathrm{ml}) ; \mathrm{Ct}=$ Konsentrasi pakanakhir $(\mathrm{sel} / \mathrm{ml})$; $\mathrm{t}=$ waktu (jam).

Kelangsungan hidup larva atau benih kerang dihitung dengan menggunakan rumus dari Effendi (1979) dengan rumus SR = $(N 1 / N O) \times 100 \%$, dimana SR = Kelangsungan hidup (\%); $\mathrm{N} 1=$ Jumlah benih akhir pengamatan (individu); N0 = Jumlah benih awal pengamatan (individu).

Aktivitas makan diketahui melalui pengamatan perubahan kepadatan pakan 
dalam media percobaan.Penurunan kepadatan pakan dalam media menggambarkan adanya konsumsi pakan. Untuk melihat aktivitas makan spat, dilakukan pengamatan terhadap kebutuhan pakan yaitu dengan menghitung selisih kepadatan pakan awal yang diberikan dan kepadatan akhir pakan yang diberikan ke air media percobaan (Winanto, 2009).

Tingkat konsumsi pakan harian diketahui dengan menghitung selisih jumlah pakan yang dikonsumsi selama satu hari dan jumlah pakan yang diberikan.

Data filtrasi yang diperoleh dalam penelitian ini disajikan dalam bentuk grafik, untuk kemudian dianalisis secara deskriptif.Analisis data menggunakan analisis sidik ragam (ANOVA) dengan taraf nyata 5 $\%$, untuk mengetahui pengaruh kecepatan filtrasi terhadap kelangsungan hidup spat kerang mutiara ( $P$. maxima). Apabila ditemukan perbedaan yang nyata maka akan dilakukan uji lanjut Beda Nyata Jujur (BNJ) pada taraf $5 \%$.

\section{Hasil}

\section{Kecepatan Pembersihan (Clearance Rate/ CR)}

Hasil penelitian dengan jenis pakan alami yang berbeda menunjukkan nilai $C R$ yang tidak berbeda secara signifikan $(p>0.05)$ baik pada pengamatan 24 jam maupun 48 jam pasca pemberian pakan. Laju $C R$ pada setiap periode pengamatan menunjukkan pola yang berbeda (Gambar $1 \& 2)$.

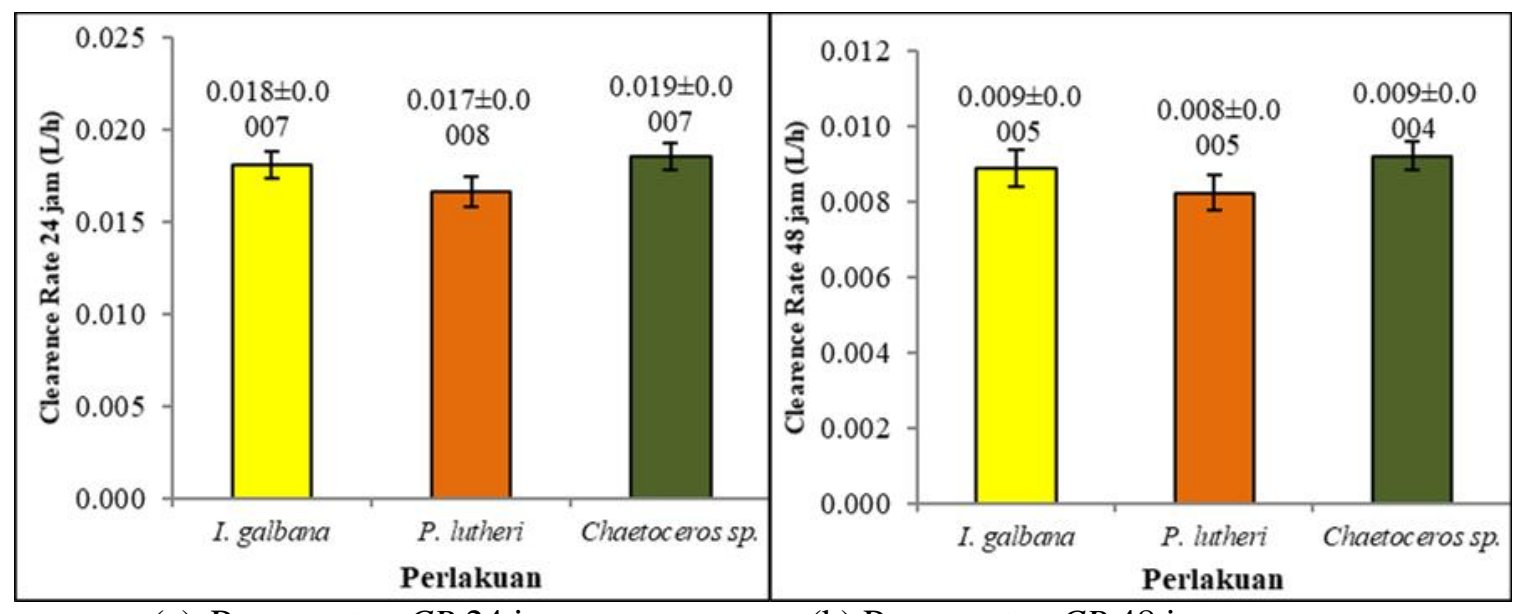

(a) Pengamatan $C R 24$ jam

(b) Pengamatan $C R 48$ jam

Gambar 1. Kecepatan pembersihan total partikel tersuspsensi (Clearance Rate) spat kerang mutiara (P. maxima).

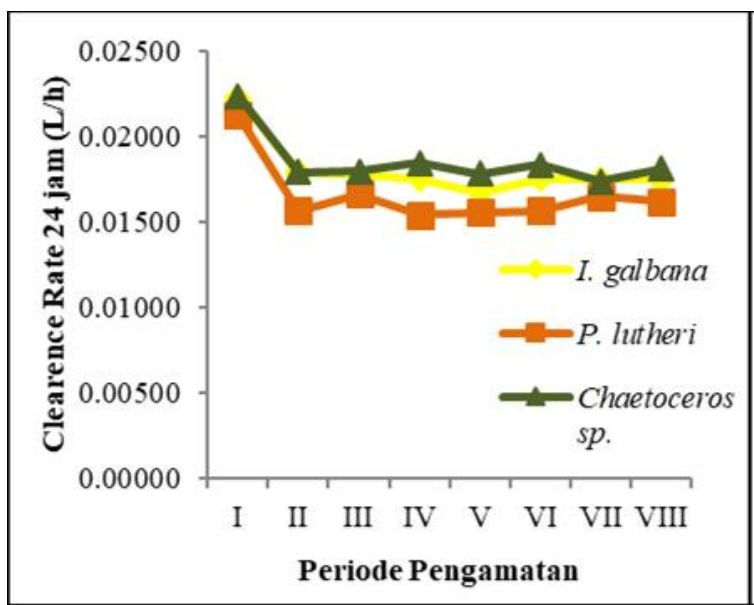

(a) Pengamatan $C R 24$ jam

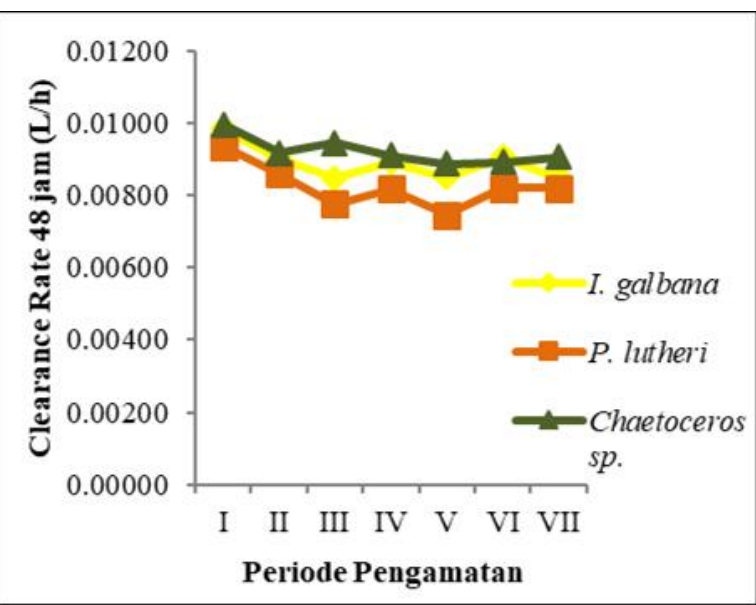

(b) Pengamatan $C R 48$ jam

Gambar 2. Pola dari kecepatanpembersihan total partikel tersuspsensi (Clearance Rate) spat kerang mutiara ( $P$. maxima) setiap pengamatan. 


\section{Kecepatan Filtrasi (Filtration Rate/FR)}

Hasil penelitian dengan perlakuan jenis pakan alami yang berbeda menunjukkan nilai kecepatan filtrasi yang tidak berbeda secara signifikan $(p>0.05)$ baik pada pengamatan 24 jam maupun 48 jam pasca pemberian pakan.Namun demikian, kecepatan filtrasi pada setiap periode pengamatan menunjukkan pola yang berbeda (Gambar 3 dan 4).

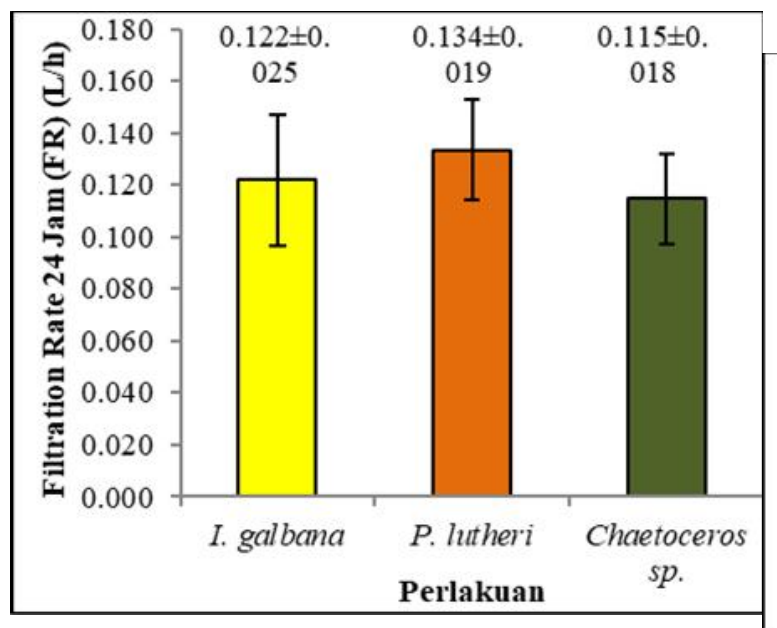

(a) Pengamatan FR 24 jam

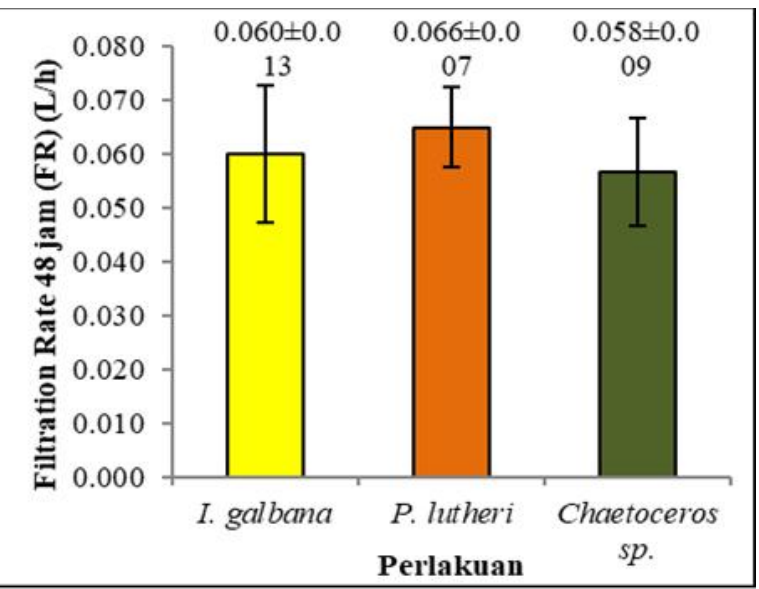

(b) Pengamatan $F R 48$ jam

Gambar 3. Kecepatan total filtrasi spat kerang mutiara spat kerang mutiara (P. maxima).

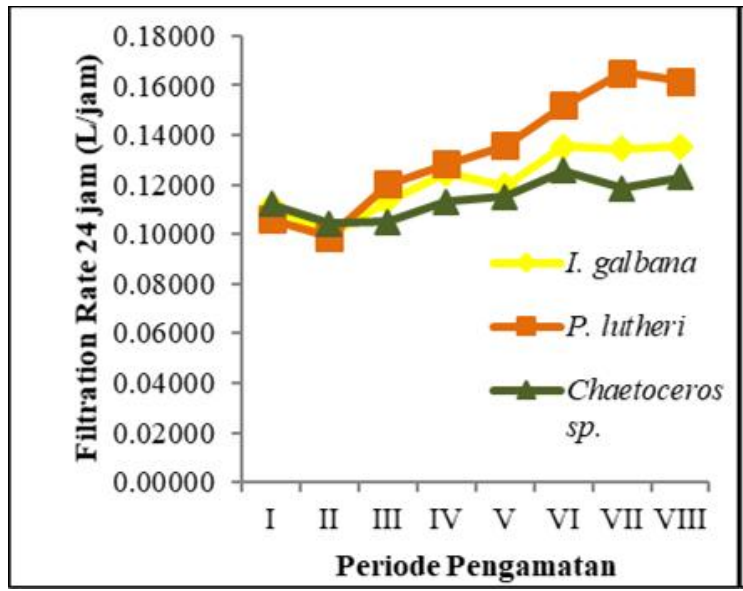

(a) Pengamatan FR 24 jam

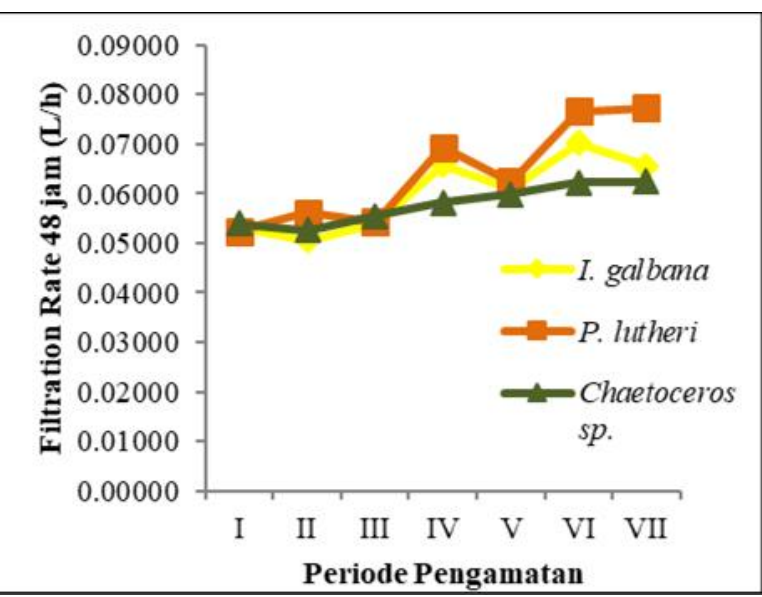

(b) Pengamatan $F R 48$ jam

Gambar 4. Pola dari kecepatantotal filtrasi spat kerang mutiara (P. maxima) setiap pengamatan. 


\section{Aktivitas Makan}

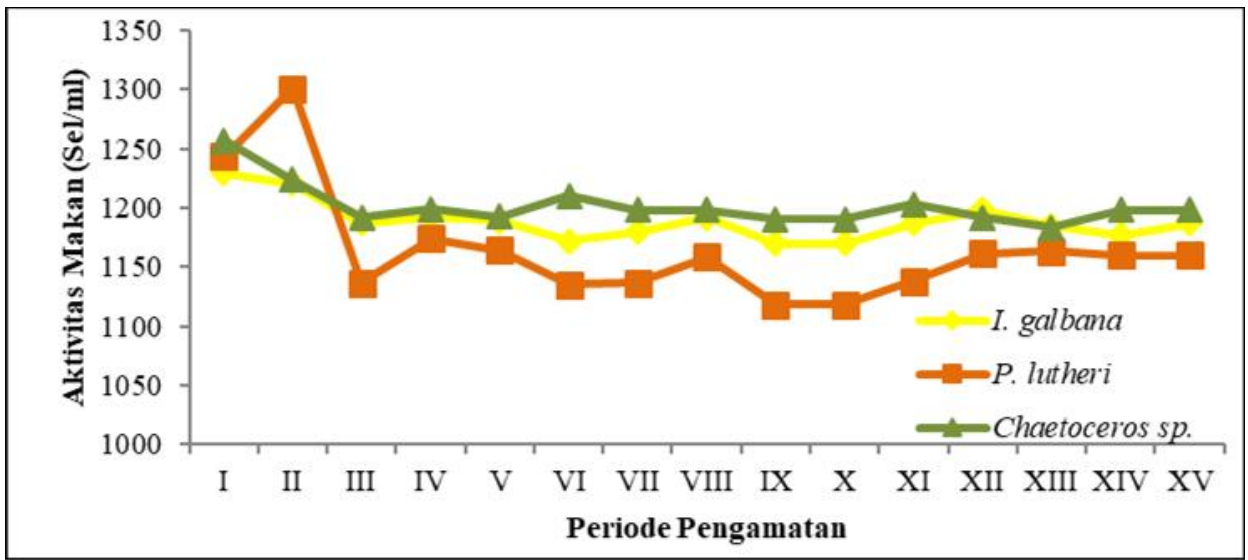

Gambar 5. Pola dari aktivitas makan spat kerang mutiara (P. maxima) setiap periode pengamatan.

\section{Tingkat Konsumsi Pakan Harian}

Hasil penelitian dengan menggunakan jenis pakan yang berbeda menunjukkan nilai tingkat konsumsi pakan harian berbeda secara signifikan $(p<0.05)$. Terlihat dalam Gambar 7 , bahwa Chaetoceros sp. memiliki nilai tingkat konsumsi pakan harian lebih tinggi dibandingkan perlakuan lainnya.

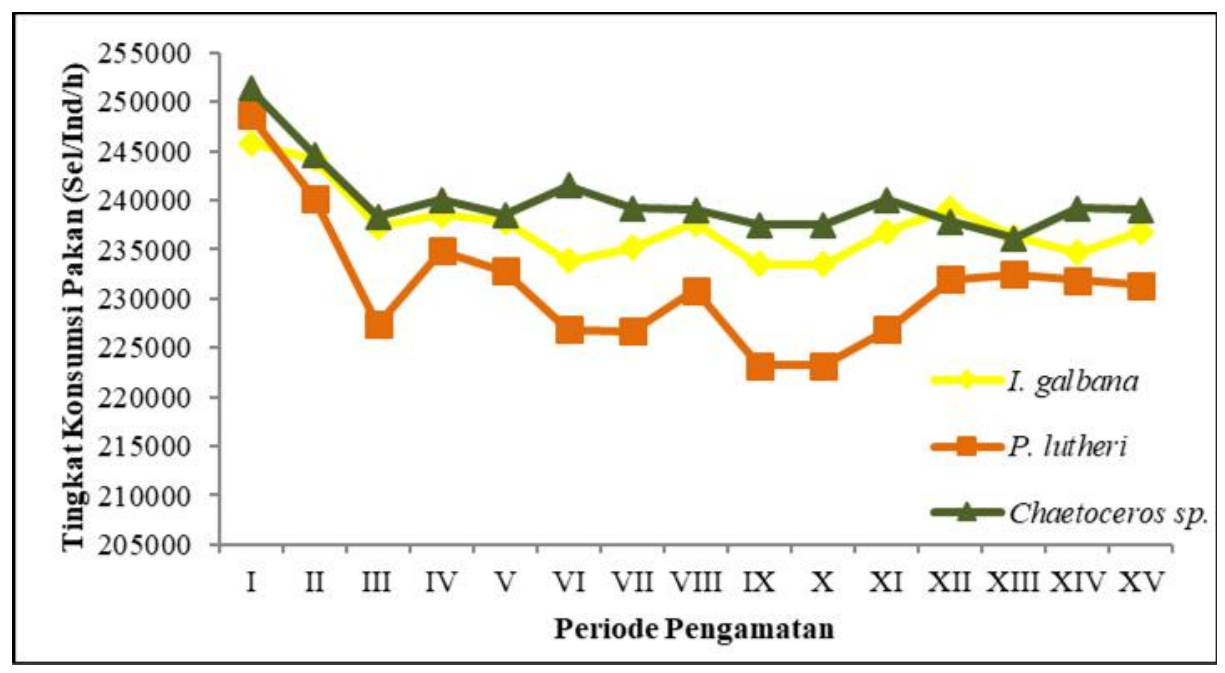

Gambar 7. Pola dari tingkat konsumsi pakan harian spat kerang mutiara ( $P$. maxima) selama pemeliharaan pada setiap pengamatan.

\section{Tingkat Kelangsungan Hidup}

Berdasarkan analisis sidik ragam (ANOVA) menunjukkan bahwa kecepatan filtrasi dengan jenis pakan yang berbeda memberikan pengaruh nyata $(p<0.05)$ terhadap kelangsungan hidup spat kerang mutiara (P. maxima). Berdasarkan analisis sidik ragam (ANOVA) menunjukkan bahwa kecepatan filtrasi dengan jenis pakan yang berbeda memberikan pengaruh nyata $(p<0.05)$ terhadap kelangsungan hidup spat kerang mutiara ( $P$. maxima). 
Tabel 1.Tingkat kelangsungan hidup spat kerang mutiara (P. maxima) (rata-rata $\pm \mathrm{SD}$ ) pada perlakuan pakan yang berbeda.

\begin{tabular}{lc}
\hline \multicolumn{1}{c}{ Perlakuan } & Tingkat Kelangsungan Hidup (\%) \\
\hline I. galbana & $76.00 \pm 16.73^{\mathrm{a}}$ \\
P. lutheri & $48.00 \pm 10.95^{\mathrm{b}}$ \\
Chaetoceros $\mathrm{sp}$. & $76.67 \pm 19.66^{\mathrm{a}}$ \\
\hline
\end{tabular}

Keterangan : superscript $=$ notasi beda nyata $(a=5 \%)$

\section{Pembahasan}

\section{Kecepatan Pembersihan (Clearance Rate) CR)}

Kecepatan pembersihan adalah kemampuan hewan uji dalam menyaring partikel di dalam air, terutama dalam bentuk partikel tersuspensi (Supriyantini, 2012). Parameter ini penting untuk menentukan kemampuan hewan uji dalam menyaring (membebaskan) partikel tersuspensi dalam air per unit waktu. Partikel tersuspensi dalam penelitian ini dimaksudkan adalah pakan alami yang menjadi perlakuan uji. Terlihat dalam Gambar 1, bahwa Chaetoceros sp. memiliki nilai $C R$ yang relatif lebih tinggi dibandingkan dengan perlakuan lainnya. Namun lebih lanjut jika diamati dari pola $C R$ tiap periode pengamatan dalam Gambar 2, tidak menunjukkan pola yang memiliki perbedaan ekstrim. Hal ini terlihat dari pola gambar yang serupa untuk tiap perlakuan pada tiap-tiap pengamatan. Relatif lebih baiknya Chaetoceros sp. pada parameter $C R$ ini, diduga disebabkan oleh ukuran sel dari Chaetoceros sp. yang lebih kecil dibandingkan jenis pakan lainnya, selain itu Chaetoceros sp. juga diketahui memiliki pola gerakan yang pasif, sehingga memudahkan bagi spat untuk melakukan pembersihan $(C R)$ dibandingkan perlakuan lainnya (Martosudarmo \& Wulani, 1990). Hal ini sesuai dengan pernyataan Wilbur dan Yonge (1966); Omari dan Ikeda (1984) bahwa pemangsaan fitoplankton itu berdasarkan ukuran sel fitoplankton.

\section{Kecepatan Filtrasi (Filtration Rate/FR)}

Kecepatan filtrasi (filtration rate) adalah volume air yang bebas partikel dalam satuan waktu. Kecepatan filtrasi dapat dihitung dari penurunan eksponensial konsentrasi partikel yang terjadi selama proses pemakanan (Bayne, 1976). Hal ini dapat terjadi dengan asumsi terjadi pemanfaatan (pemakanan) plankton oleh hewan uji, dalam hal ini spat kerang mutiara (P. maxima). Disamping itu, asumsi lain yaitu media tempat perlakuan dikondisikan dalam keadaan gelap dan juga umur plankton yang diberikan pada media tempat perlakuan berada pada umur kultur 4 hari atau fase stasioner yaitu faktor pembatas dan kecepatan tumbuh sama karena jumlah sel yang membelah dan yang mati seimbang, sehigga pertumbuhan plankton dapat ditekan seminimal mungkin dengan mengurangi intensitas cahanya yang diperlukan untuk fotosintesis. Kerang melakukan filtrasi siang hari maupun malam hari (Riisgard, 2001). Kerangmenyerap dan menyaring semua bahan yang telah tersaring tetapi tidak semua yang disaring masuk ke lambung. Disamping itu penyaringan yang dilakukan oleh kerang berlangsung secara terus menerus selama 24 jam (Tan, 1973),sehingga dengan demikian penyaringan yang dilakukan oleh kerang berlangsung secara maksimal. Terlihat dalam Gambar 3, bahwa Chaetoceros sp. relatif lebih rendah dibandingkan dengan perlakuan lainnya. Namun lebih lanjut jika diamati dari pola kecepatan filtrasi setiap periode pengamatan dalam Gambar 4, tidak menunjukkan pola yang jauh berbeda. Hal ini terlihat dari pola gambar yang serupa untuk tiap perlakuan pada tiap-tiap pengamatan. Relatif lebih rendahnya Chaetoceros sp. pada parameter kecepatan filtrasi ini, diduga disebabkan oleh pembelahan sel pada Chaetoceros sp. diketahui lebih cepat dan berlangsung secara kontinyu yang mengakibatkan terjadinya penurunan ukuran hingga mencapai 3-7,5 $\mathrm{m}$ dalam periode waktu tertentu sehingga menyebabkan konsentrasi jenis pakan ini relatif lebih tinggi dibandingkan dengan perlakuan lainya (Winanto, 2004).

Bervariasinya kecepatan filtrasi terhadap konsentrasi baik partikel tersuspensi maupun partikulat (deposit) dikarenakan pola adaptasi kerang selama proses penyerapan dan penyaringan terhadap partikel memilliki fase 
tertentu. Dimana, pada saat konsentrasi rendah sampai batas atau tingkat tertentu, peningkatan konsentrasi partikel akan diiringi dengan peningkatan kecepatan filtrasi secara linier. Namun, pada saat peningkatan partikel terlalu tajam, dalam arti konsentrasi dalam perairan sangat tinggi maka kerang akan mengurangi penyerapan terhadap partikel, sehingga kecepatan filtrasi kerang cenderung menurun (Putra, 2006).

\section{Aktivitas Makan}

Aktivitas makan diketahui melalui pengamatan perubahan kepadatan pakan dalam media percobaan. Penurunan kepadatan pakan dalam media percobaan menggambarkan adanya konsumsi pakan. Untuk melihat aktivitas makan spat, diketahui dengan menghitung selisih kepadatan pakan awal yang diberikan dan kepadatan akhir pakan yang diberikan ke air media percobaan (Winanto, 2004). Relatif lebih tingginya Chaetoceros sp. pada parameter ini, diduga disebabkan oleh pola gerakan dari Chaetoceros sp. yang lebih pasif dibandingkan dengan perlakuan lainnya, selain itu Chaetoceros sp. juga diketahui memiliki warna yang lebih kontras dengan air, sehingga lebih menarik untuk dikonsumsi oleh spat (Winanto, 2009).
Selain pengamatan perubahan kepadatan, terjadinya aktivitas makan juga dapat dilihat berdasarkan penampakan fisik media percobaan dalam penelitian. Salah satunya dengan melihat warna air media percobaan. Berdasarkan penampakan fisik, warna air media percobaan dari awal pengamatan sampai akhir menunjukkan perbedaan yang cukup signifikan (Gambar 6). Terlihat bahwa kecenderungan warna media percobaan semakin lama semakin jernih. Dalam waktu 24 jam dengan 5 ekor spat kerang dan volume 5 liter terlihat perbedaan kejernihan air. Hal ini mengindikasikan bahwa terjadinya berberapa hal yang berhubungan dengan aktivitas makan terhadap pakan di dalam media percobaan. Pertama, dengan adanya perubahan warna dari keruh ke lebih jernih, berarti hewan uji (spat) melakukan aktivitas makan (mengkonsumsi makanan) terhadap partikel pakan yang ada dalam media percobaan (aktivitas makan spat efektif), dengan asumsi proses sedimentasi tidak mempengaruhi keberadaan partikel pakan tersuspensi. Proses sedimentasi relatif kecil karena adanya aerasi selama pengamatan. Kedua, jika aktivitas makan spat tidak efektif maka yang dominan terjadi adalah proses sedimentasi meskipun proses aerasi tetap berlangsung.

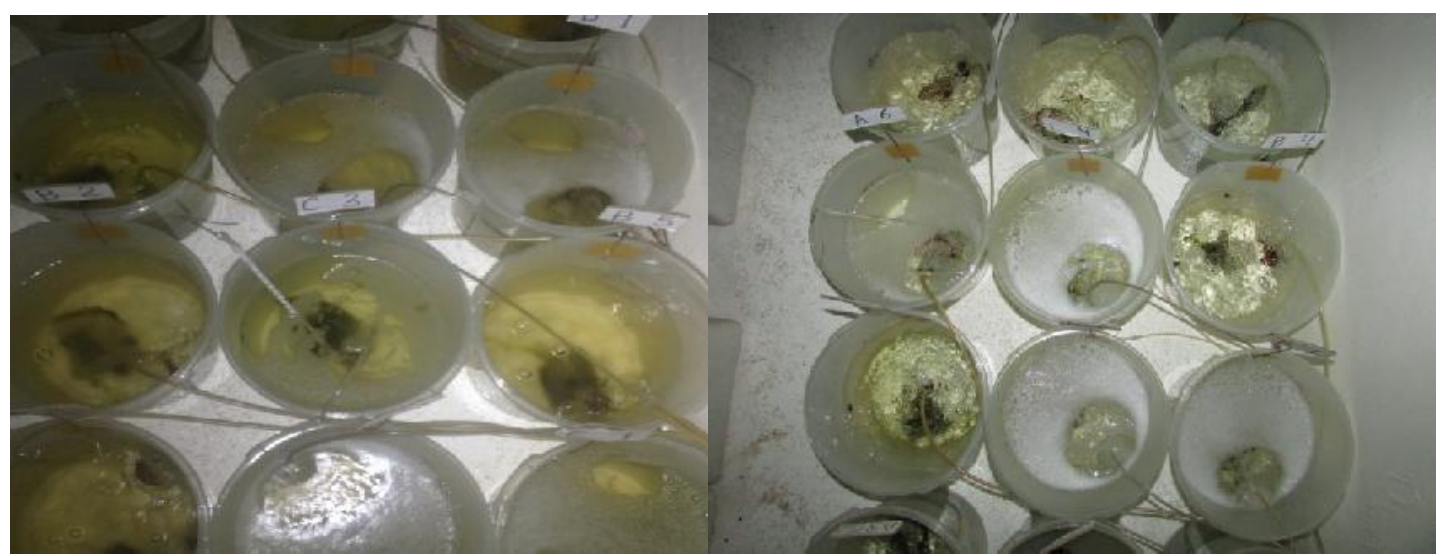

(a) Saat ditambah pakan 0 jam (b) Setelah 24 jam

(Dokumentasi Pribadi, 2017)

Gambar 6. Perubahan warna media percobaan selama terjadi aktivitas makan.

\section{Tingkat Konsumsi Pakan Harian}

Tingkat konsumsi pakan harian diketahui dengan menghitung jumlah pakan yang dikonsumsi selama satu hari dan jumlah pakan yang diberikan per sel per individu per hari.lebih tinggi. Chaetoceros lebih tinggi dikonsumsi,hal ini diduga disebabkan oleh kandungan nutrisi dari Chaetoceros sp. yang dibandingkan dengan pakan lainnya, selain itu Chaetoceros sp. juga diketahui memiliki ukuran sesuai dengan bukaan mulut organisme pemakannya, sehingga dalam periode waktu tertentu menyebabkan jenis pakan ini relatif lebih banyak dikonsumsi dibandingkan pakan 
lainnya (Winanto, 2004). Preferensi spat terhadap pakan sangat tergantung pada ukuran dan spesies, masing-masing jenis kerang mempunyai kemampuan yang berbeda-beda dalam memilah dan mengambil makanan yang disukai. Pada prinsipnya, mikroalga yang digunakan sebagai pakan spat kerang atau organisme laut lainnya adalah mempunyai ukuran yang tepat untuk dimakan atau sesuai dengan bukaan mulut larva/spat, mempunyai kandungan nutrisi tinnggi, mudah dibudidayakan, cepat tumbuh dengan kepadatan tinggi dan tidak menghasilkan substansi racun (Coutteau dan Sorgeloos, 1996; Ponis et al., 2006).

\section{Tingkat Kelangsungan Hidup}

Tingkat kelangsungan hidup adalah peluang hidup suatu individu dalam waktu tertentu. Parameter ini sangat penting untuk menentukan produksi yang diperoleh dan erat kaitannya dengan ukuran organisme yang dipelihara.Terlihat dalam Tabel 1, bahwa Chaetoceros sp. memiliki persentase kelangsungan hidup lebih tinggi dibandingkan perlakuan lainnya. Hal ini diduga disebabkan oleh nilai nutrisi dari Chaetoceros sp. lebih tinggi dibandingkan perlakuan lainnya, Taufiq dkk. (2007) mengatakan bahwa kandungan kalsium (Ca) dan phospor (P) di dalam Chaetoceros sp. termasuk paling tinggi di antara jenis plankton yang lain. Kandungan $\mathrm{Ca}$ dalam Chaetoceros sp. sebesar 0,59\% dan kandungan P mencapai 0,57\%. Kekurangan Ca dan $\mathrm{P}$ pada pakan akan mengakibatkan rendahnya pertumbuhan dan rendahnya efisiensi pakan. Selain itu Chaetoceros sp. juga diketahui memiliki ukuran sel lebih kecil yang mengakibatkan spat lebih mudah menyerap dan mencerna pakan ini, sehingga dapat mensuplai energi untuk melakukan absorsi dan metabolisme dalam mendukung kelangsungan hidup spat (Taufiq et al., 2007).

\section{Kesimpulan}

Berdasarkan dari hasil penelitian dapat disimpulkan bahwa, analisis kecepatan filtrasi dengan jenis pakan yang berbeda berpengaruh terhadap kelangsungan hidup spat kerang mutiara ( $P$. maxima). Perlakuan pemberian pakan Chaetoceros sp. mampu memberikan kelangsungan hidup tertinggi sebesar $(76.67 \% \pm 19.66)$, dan memiliki nilai aktivitas makan lebih tinggi sehingga dapat dikatakan bahwa pakan Chaetoceros sp. lebih baik dan lebih disukai oleh spat kerang mutiara $(P$. maxima).

\section{Daftar Pustaka}

Antoro, S dan L. Erawati. (2001). Rekayasa Teknik Pembeihan Tiram Mutiara (Pinctada maxima, Jemeson) di Laboratorium; Laporan Tahunan BBL Lampung th 2000. DKP, Dirjen Perikanan Budidaya, BBL Lampung. Hal: 72-81.

Adiguna, L. W. 2004. Pengaruh Pemberian Pakan Alami dengan Jenis yang Berbeda Terhadap Perkembangan dan Kelulusan Hidup Larva Tiram Mutiara (Pinctada maxima, Jameson) Dalam Bak Pendederan. [Skripsi Unpublished]. Fakultas Perikanan Univesitas Brawijaya. Malang.

Bayne, B.L. 1976. Marine Mussels :Their Ecology and Physiology. International Biologycal Programme; 10. Cambridge University Press. London. Hal 13-60.

Coutteau, P. dan P. Sorgeloos. 1996. The Uses of Algal Substitutes and The Requirenents for Live Algae in Hatchery and Nursery rearing of Bivalve Molluscs: An International Survey. J Shellfish Res. Hal :467-476.

Dhoe, S.B, Supriya, dan E. Juliaty. 2001. Biologi Tiram Mutiara: Juknis Pemeliharaan Tiram Mutiara (Pinctada maxima). BBL Lampung, Lampung. Hal : 2-12.

Effendi, M. I. 1979. Biologi Perikanan Bagian I. Fakultas Perikanan, Institut Pertanian Bogor. Bogor.

Hamzah, M.S. 2008.Studi tingkat mortalitas anakan kerang mutiara Pinctada maxima dikaitkan dengan variasi musiman kondisi suhu laut di Perairan Teluk Kombal, Lombok Barat dan Teluk Kapontori, Pulau Buton.Prosiding Seminar Moluska dalama Penelitian, Konservasi dan Ekonomi.

Kordi, K.M.G.H. 2011.Budi Daya 22 Komoditas Laut Untuk Konsumsi Lokal dan Ekspor. Yogyakarta: ANDI OFFSET. Hal :16 - 17.

Martosudarmo, B dan I. Wulan. 1990. Petunjuk Pemeliharaan Kultur Murni dan Massal Microalga.United Nations Development Programme Food and Agriculture organization of the United 
Nations. Subcenter Udang Jawa Timur. Hal :50.

Omari, M. dan T. Ikada. 1984. Methods in Marine Zooplankton Ecology. A-Willey Interscience Publication. New York. Hal : 159-164.

Petersen, J. K., S. Bourier, A.C. Smaal, P. Garen, S. Robert, J. E. N. Larsen, dan E. Brummelhius. 2004. Intercalibration of Mussel Mytilus edulis Clearance Rate Meansurements. Mar. Eco. Prog. Ser. Hal :187-194

Ponis E, Probert I, Veron B, Le Coz JR, Mathieu M, Robert R. 2006. Nutritional Value of Six Pavlovacceae for Crassostrea gigas and Pecten maxima Larvae. Aquaculture. Hal :544-553.

Putra, W.S. 2006. Laju Filtrasi Kerang Hijau (Perna viridis L. 1758) Dalam Mereduksi Bahan Tersuspensi. [Skripsi Unpublished]. Jurusan Ilmu Kelautan, Fakultas Perikanan dan Ilmu Kelautan, Uneversitas Diponegoro. Semarang.

Riisgard, H.U. 2001. On Meansurement of Filtration Rate in Bivalve - the Stony Road to Reliable Data : Review and Interpretation Data. Mar. Eco. Prog. Ser. Hal :275-291.
Supriyantini, E. 2012. Laju Filtrasi Kerang Totok Polymesoda erosa terhadap Pakan Alami Skeletonema costatum dan Tetraselmis chuii. Buletin Oseanografi Marina, Uneversitas Diponegoro, Semarang. Vol. 1Hal :41 - 46.

Tan, W. H. 1973. Egg and Larval Development in the Green Mussel, Mytilus viridis Linneaus. The Veliger. Vol. 18 (2) : 151-155.

Taufiq, Nur, R. Hartati, J. Cullen dan J.M. Masjhoer. 2007. Pertumbuhan Tiram Mutiara (Pinctada maxima) pada Kepadatan Berbeda.Ilmu Kelautan. Vol. 12 (1) : 31-38.

Winanto, T. 2004. Memproduksi Benih Tiram Mutiara. Penebar Swadaya. Jakarta.

Winanto, T. 2009.Kajian Perkembangan Larva dan Pertumbuhan Spat Tiram Mutiara Pinctada maxima (Jameson) Pada Kondisi Lingkungan Pemeliharaan Berbeda. Disertasi. Institut Pertanian Bogor. Bogor.

Winanto, T., L. Erawati dan Kuswadi. 2003. Rekayasa Teknologi Produksi Spat Tiram Mutiara. Laporan Tahunan, Balai Budidaya Laut, Lampung. 